\title{
Water Health Status in Lower Reaches of River Ganga, India
}

\author{
Chitralekha Sengupta ${ }^{1}$, Dipu Sukumaran ${ }^{1, *}$, Dipanjali Barui ${ }^{1}$, Rita Saha ${ }^{1}$, Abhijit Chattopadhyay ${ }^{1}$, Asish Naskar ${ }^{1}$, \\ Suneel Dave ${ }^{2}$ \\ ${ }^{1}$ Central Pollution Control Board, Southend Conclave, Block, Rajdanga Main Road, Kolkata \\ ${ }^{2}$ Central Pollution Control Board, Parivesh Bhavan, New Delhi, India \\ *Corresponding author: dipudr@rediffmail.com
}

Received January 01, 2014; Revised January 10, 2014; Accepted January 20, 2014

\begin{abstract}
Several factors affect microorganism survival and distribution in the aquatic environment including humans and animal populations. Present study assessed the influence of physicochemical factors on the distribution of presumptive coliform along the stretch of River Ganga in West Bengal, India. Nevertheless, Ganga water is polluted by drainage waste released from various urban and rural regions, agricultural and domestic wastes, industrial effluents and human activities. Drains discharge major portions of domestic wastes and untreated sewages, into the aquatic environment. Physico-Chemical factors affecting the survival of fecal microorganisms in the River Ganga as per the study included parameters like $\mathrm{pH}$, conductivity, alkalinity, biochemical oxygen demand (BOD), chemical oxygen demand (COD) etc. In Ganga some parameters were seen to vary dramatically along the stretch. All the stations had the total coliform counts of more than 500 and Tribeni being the upstream station had lower value for coliforms. Ganga Sagar was found to have the least count for coliforms because of high salinity.
\end{abstract}

Keywords: River Ganga, faecal coliform, total coliform, drains

Cite This Article: Chitralekha Sengupta, Dipu Sukumaran, Dipanjali Barui, Rita Saha, Abhijit Chattopadhyay, Asish Naskar, and Suneel Dave, "Water Health Status in Lower Reaches of River Ganga, India." Applied Ecology and Environmental Sciences 2, no. 1 (2014): 20-24. doi: 10.12691/aees-2-1-3.

\section{Introduction}

Rivers of India play an important role in the lives of the Indian people. The river systems provide irrigation, potable water, cheap transportation, electricity, and the livelihoods for a large number of people all over the country and to rural areas. This easily explains why nearly all the major cities of India are located by the banks of rivers. West Bengal is a land of rivers and constitutes three major river systems, namely, the Ganga, the Brahmaputra and the Subarnarekha. The Ganga and the Brahmaputra meet each other in Bangladesh to form the largest delta of the world before meeting the Bay of Bengal. However, Ganga drainage system covers most part of West Bengal.

Rivers are one of the foremost vital habitats of fresh water and so must receive a lot of attention. Organic contaminants entering from industrial, urban and agriculture waste to aquatic environment increases the biochemical oxygen demand [1,2]. Regarding to increment of organic and contaminated material that have to be decomposed within the riverine environment, microorganism consume great amount of the dissolved oxygen $[3,4]$. As a result, the oxygen in water is greatly reduced, and consequently disrupts the aquatic life. Entrance of chemical fertilizers, pesticides and industrial, social unit and hospital waste into water sources not only pose a serious threat to water resources but have led to serious problems in the nature [5].

River Ganga is $2525 \mathrm{~km}$ long and accounts for 26.3\% [7] of the total geographic area of India. In west Bengal Ganga stretches 540 km. in India Ganga drains eight states in which west Bengal shares 8.4 percent of the total area drained by this holy river. However, the riverine ecology has become highly disturbed because of the high degree of pollution. Seeing this National Ganga river basin authority has launched a project to clean Ganga and given some part of the monitoring work to Central pollution control board under the ministry of environment and forest, government of India. Since proper sewerage is not available, riverine banks are often used for open defecation. The authors were further interested to find the distribution of coliforms throughout the stretch. This has aggravated the pollution problems further. Total coliform and faecal coliform counts are the most widely used bacteriological procedures for water quality assessment [8] and surprisingly coliform contamination has been observed in the areas nearer to the origin of the river Ganges [9]. Hence, the sole objective of this paper is to find if any correlation exists between biological pollution and other physic-chemical parameters and if yes, then to what extent.

Septic systems which are improperly set, not maintained, or bypassed, contribute biological contaminants to streams through surface or groundwater flows. The key pollutants in runoff from urban area are 
sediment, nutrients, oxygen-demanding wastes, road salts, heavy metals, fossil fuel hydrocarbons, microorganism, viruses, toxic chemicals etc. These are generated directly from the pesticides, road salts, and fertilizers, and indirectly from automobile exhaust, oil drippings from automobiles and numerous urban activities [9]. A study conducted by Young and Thackston [10] on microorganism loading in urban streams, found that fecal bacteria densities were directly connected to the density of housing, population, development, percent impervious area, and density of domestic animal. Improper landscaping practices may be a supply of excessive levels of fecal coliform and nutrients. Improperly applied and inadequately composed manure product also contributes to fecal microorganism. Fertilizing lawns and gardens beyond the agronomic uptake by plants impart nutrients in the storm water runoff. There is worldwide concern about faecal contamination of water bodies and therefore the resulting impact on human health. There has been research on Best Management Practices to cut down untreated human and animal waste discharge, however our understanding of microorganism dynamics inside a watershed remains imperfect [11,12]. In recent decades, the Ganga has also been recognized as one of the most seriously polluted of the major rivers of the world its water quality being threatened by extensive dumping of untreated sewage and chemical waste [13].Water in the Ganges has been correlated to contracting dysentery, cholera, hepatitis, as well as severe diarrhea which continue to be one of the leading causes of death of children in India [14]. Anjum et al. [15] studied the seasonal variation of different physicochemical parameters of Ganga River.

\section{Materials and Methods}

\subsection{Study Area}

The study was conducted during December, 2012 on the stretch of Ganga in West Bengal. Sixteen stations were selected for this study. The map of the study area is given in Figure 1 . The area of study covers between

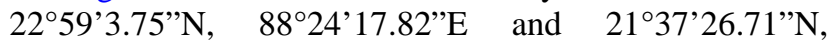
88॰4'45.25”'E.

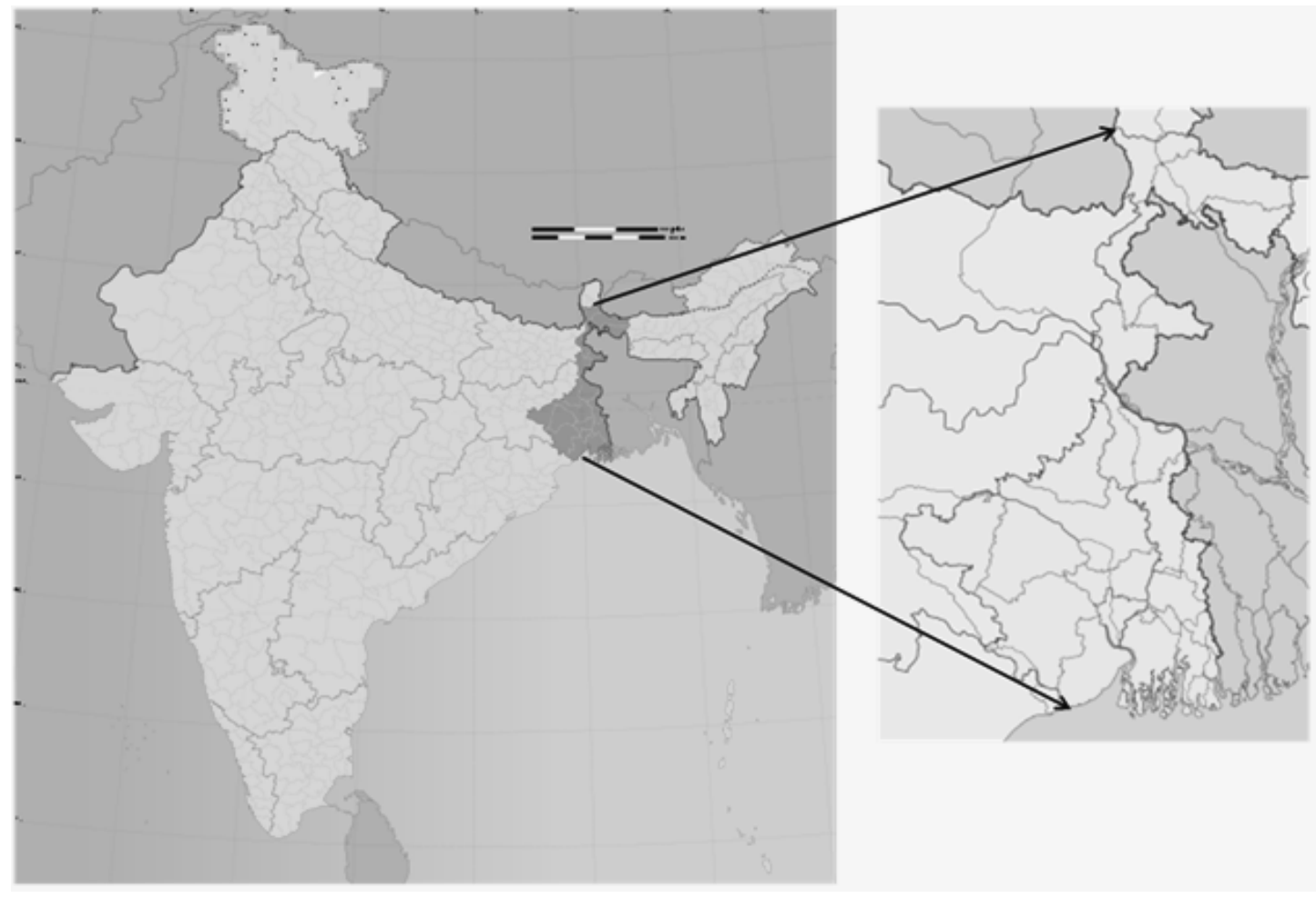

Figure 1. Map of study area

\section{Methodology}

The study was conducted on winter season in 2012. All samples were collected from the mid stream of the river in different capacity containers. Microbial samples were collected separately in $100 \mathrm{ml}$ sterilized glass bottles. The methods of the respective parameters are given in parentheses. Physicochemical analyses of chemical oxygen demand (5220-B), biological oxygen demand (BOD), total dissolved solids (2540C), total hardness (2340C), alkalinity (2320B), chloride (4500-Cl-B), nitrate $\left(4500-\mathrm{NO}_{3}-\mathrm{B}\right)$ and nitrite $\left(4500-\mathrm{NO}_{2}-\mathrm{B}\right)$, phosphate
(4500-P D), total coliforms (9221-B) and faecal coliforms (9221-B) of water were analyzed following the methods of APHA [16]. pH was measured on site by a digital electronic $\mathrm{pH}$ meter (WTW-330i-pH), while conductivity (2510B) was measured by conductivity meter (WTW330i-cond). All the samples were stored preserved in ice immediately after collection and were analyzed within 24 hours from the time of collection. The limits set by WHO for drinking water and designated best use by Central Pollution Control Board [17] were considered as standard for the study of the above mentioned parameters.

Chemical oxygen demand was determined by digesting the samples using open reflux method followed by titration of the remaining potassium dichromate with 
ferrous ammonium sulphate. Five days \pm 6 hours BOD test was conducted as incubate at $20 \pm 1^{\circ} \mathrm{C}$. Alkalinity was determined by titrimetric method where methyl orange indicator and titrated with sulphuric acid. Total dissolve solids was determined by gravimetric method. Phosphate was determined by colorimetric method in which stannous chloride was used as reducing agent and optical density was measured at $690 \mathrm{~nm}$. Nitrite nitrogen was determined by colorimetric method at $543 \mathrm{~nm}$ while nitrate nitrogen was determined by cadmium reduction method then the colour was determined similar to nitrite nitrogen.

\subsection{Microbiological Analyses}

For microbiological analyses, $100 \mathrm{ml}$ water samples were collected from sixteen study sites of the river stations. The samples were subjected to serial dilution in nutrient water containing potassium dihydrogen phosphate and magnesium chloride and inoculated in multiple tubes as per the maximum probable number method. The tubes contained $10 \mathrm{ml}$ of lauryl tryptose broth for the detection of total coliforms and faecal coliforms were incubated at $35 \pm 0.5^{\circ} \mathrm{C}$ for three hour in A1 broth [16]. For fecal coliform, the tubes were inoculated serially and were incubated for three hour at $35 \pm 0.5^{\circ} \mathrm{C}$ for three hours and transferred to a water bath at $44.5 \pm 0.2^{\circ} \mathrm{C}$ and incubated for an additional $21 \pm 2$ hour. Production of an acidic reaction or gas production in any A-1 broth culture within 24 hours or less is a positive reaction indicating the presence of fecal coliform.

\subsection{Statistical Analysis}

The data obtained on the physicochemical and microbiological parameters of the river water were subjected to correlation analysis. The correlation was carried on statistical software SPSS version 16 .

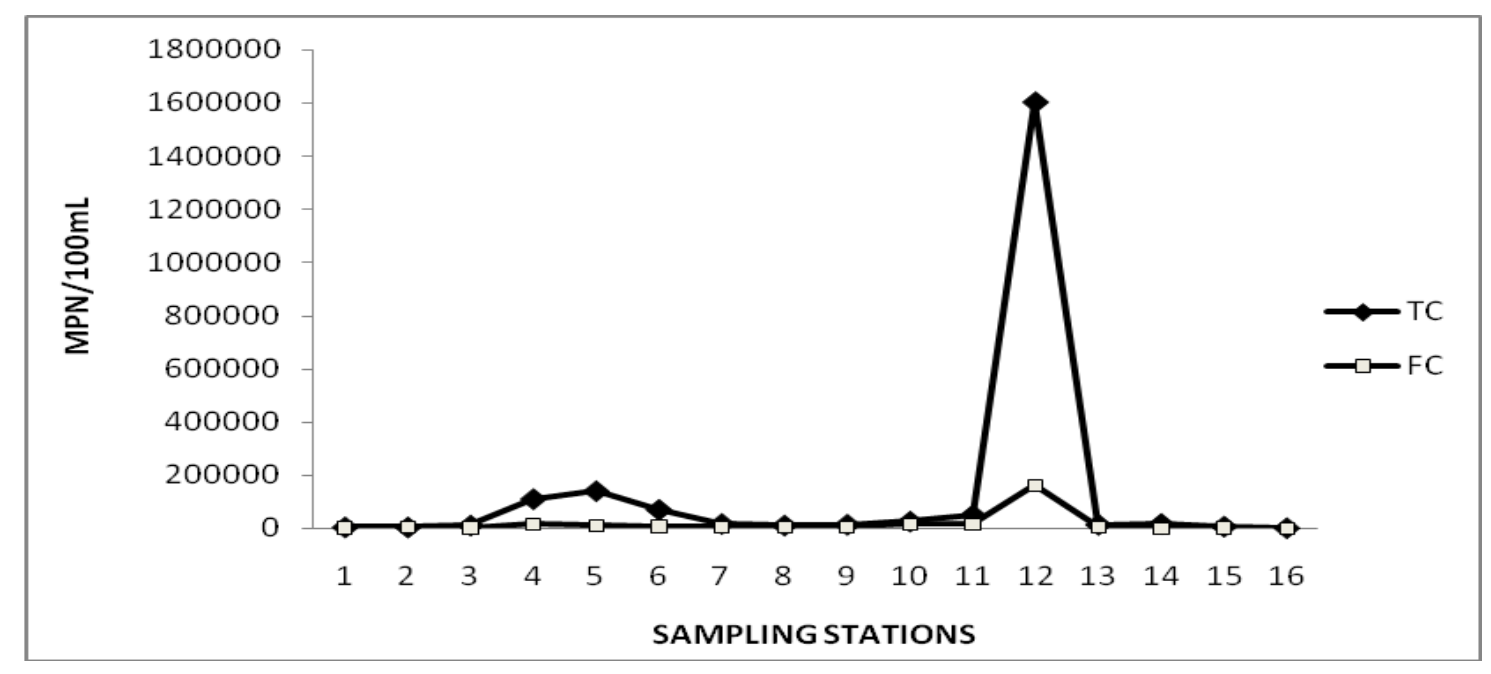

Figure 2. TC and FC count as observed in the sixteen sampling stations

\section{Results}

According to the designated best use of Central Pollution Control Board [17], all stations have violated the drinking water requirement and fall into category C, (Drinking water source after conventional treatment and disinfection) i.e., all have the total coliform counts of more than 500. Tribeni being the upstream station has lower value for coliforms. As the river approaches farther the coliform count is seen to increase with an abrupt rise in Garden Reach where the total coliform (TC) count is $1600000 \mathrm{MPN} / 100 \mathrm{ml}$ and faecal coliform (FC) count is $160000 \mathrm{MPN} / 100 \mathrm{ml}$. However, the count then falls and at the last station i.e., Ganga Sagar, the count terribly drops to $1100 / 100 \mathrm{ml}$ for TC and only $20 / 100 \mathrm{ml}$ for FC. The trend of TC and FC is depicted in Figure 2. The results of the analysis is given in the Table 2 .

The $\mathrm{pH}$ does not fluctuate much ranging and is within 7.2-8.1 whereas there is a lot of difference in conductivity in the river stretch (324-23870 $\mu \mathrm{S} / \mathrm{cm})$. Dissolve oxygen, total suspended solids (TSS), total dissolved solids (TDS), chloride (Cl), alkalinity (ALK), biological oxygen demand (BOD), chemical oxygen demand (COD), total hardness (HARD), nitrite-nitrogen $\left(\mathrm{NO}_{2}-\mathrm{N}\right)$, nitrate-nitrogen $\left(\mathrm{NO}_{3}-\right.$
$\mathrm{N})$, phosphate $\left(\mathrm{PO}_{4}\right)$, total coliforms (TC) and faecal coliforms (FC) were in the range 6.7-8.5 mg/l, 32-125 $\mathrm{mg} / \mathrm{l}, 178-17167 \mathrm{mg} / \mathrm{l}, 9-9097 \mathrm{mg} / \mathrm{l}, 108-164 \mathrm{mg} / \mathrm{l}, 5.2-$ $37.6 \mathrm{mg} / \mathrm{l}, 5.2-37.6 \mathrm{mg} / \mathrm{l}, 96-2900 \mathrm{mg} / \mathrm{l}, 0.007-0.038 \mathrm{mg} / \mathrm{l}$, 0.233-2.292 mg/l, 1100-16 x $10^{5}$ MPN/100 ml, 20-1600 MPN/100 ml, respectively.

Table 1. The Pearson's Correlation between physico-chemical parameters and TC and FC

\begin{tabular}{|c|c|c|}
\hline & TC & FC \\
\hline FC & $0.993^{* *}$ & 1 \\
\hline BOD & 0.328 & 0.381 \\
\hline COD & -0.178 & -0.221 \\
\hline TSS & 0.462 & 0.475 \\
\hline TDS & -0.089 & -0.112 \\
\hline ALK & 0.220 & 0.233 \\
\hline THARD & -0.091 & -0.115 \\
\hline $\mathrm{Ca}$ & -0.088 & -0.113 \\
\hline $\mathrm{Mg}$ & -0.091 & -0.115 \\
\hline $\mathrm{pH}$ & -0.062 & -0.072 \\
\hline $\mathrm{COND}$ & -0.089 & -0.112 \\
\hline $\mathrm{DO}$ & -0.277 & -0.246 \\
\hline $\mathrm{Cl}$ & -0.089 & -0.112 \\
\hline $\mathrm{PO}_{4}$ & $0.969^{* *}$ & $0.975^{* *}$ \\
\hline $\mathrm{NO}_{3}$ & 0.027 & 0.063 \\
\hline $\mathrm{NO}_{2}$ & $0.564^{*}$ & $0.588^{*}$ \\
\hline $\mathrm{COIr}^{*}$ & & \\
\hline $\mathrm{TH}^{*}$ & $\mathrm{VariO}$ & $\mathrm{Para}$ \\
\hline
\end{tabular}

The correlations between various parameters with TC and FC as observed in the study sites are given in Table 1. The correlation results depict that TC and FC are highly 
correlated ( $r=0.993$ at $1 \%$ level of significance) but they do not show any correlation with the other physical or chemical parameters except phosphate $(r=0.969$ with TC and $r=0.975$ with FC at $1 \%$ level of significance) with which both are highly correlated. However, there exists a moderate positive correlation of nitrite-nitrogen with TC ( $r=0.564$ at $5 \%$ level of significance) and FC ( $r=0.588$ at $5 \%$ level of significance). The expected correlation between some parameters like BOD and COD; TDS and TDS were not observed.

Table 2. Physicochemical and microbiological results of the study

\begin{tabular}{|c|c|c|c|c|c|c|c|c|c|c|}
\hline Sites & pH & Cond $(\mu \mathrm{S} / \mathrm{cm})$ & TDS (mg/L) & $\mathrm{Cl}^{-}(\mathrm{mg} / \mathrm{L})$ & Alk (mg/L) & $\operatorname{COD}(\mathrm{mg} / \mathrm{L})$ & BOD (mg/L) & $\mathrm{PO}_{4}(\mathrm{mg} / \mathrm{L})$ & TC & FC \\
\hline 1 & 7.19 & 326 & 186 & 9 & 124 & 7.2 & 1.4 & 0.03 & $140 \times 10^{3}$ & $110 \times 10^{2}$ \\
\hline 2 & 7.32 & 334 & 178 & 10 & 156 & 6.4 & 2.7 & 0.04 & $110 \times 10^{3}$ & $170 \times 10^{2}$ \\
\hline 3 & 7.71 & 336 & 182 & 9 & 148 & 11.2 & 1.25 & 0.04 & $11 \times 10^{3}$ & $22 \times 10^{2}$ \\
\hline 4 & 7.21 & 329 & 195 & 10 & 136 & 7.6 & 0.65 & 0.04 & $11 \times 10^{3}$ & $50 \times 10^{2}$ \\
\hline 5 & 7.73 & 331 & 191 & 9 & 140 & 9.2 & 0.75 & 0.043 & $14 \times 10^{3}$ & $50 \times 10^{2}$ \\
\hline 6 & 8.15 & 314 & 184 & 9 & 148 & 11.6 & 0.8 & 0.033 & $4 \times 10^{3}$ & $11 \times 10^{2}$ \\
\hline 7 & 8.07 & 327 & 188 & 9 & 152 & 9.6 & 3.55 & 0.04 & $4 \times 10^{3}$ & $30 \times 10^{2}$ \\
\hline 8 & 7.89 & 343 & 192 & 14 & 124 & 9.2 & 3 & 0.043 & $70 \times 10^{3}$ & $80 \times 10^{2}$ \\
\hline 9 & 7.93 & 321 & 185 & 9 & 164 & 6 & 2.3 & 0.043 & $17 \times 10^{3}$ & $50 \times 10^{2}$ \\
\hline 10 & 7.23 & 355 & 192 & 27 & 132 & 8 & 0.7 & 0.055 & $14 \times 10^{3}$ & $50 \times 10^{2}$ \\
\hline 11 & 7.58 & 374 & 218 & 31 & 144 & 12.8 & 1.3 & 0.054 & $17 \times 10^{3}$ & $7 \times 10^{2}$ \\
\hline 12 & 7.63 & 640 & 381 & 106 & 136 & 13.6 & 0.8 & 0.054 & $7 \times 10^{3}$ & $17 \times 10^{2}$ \\
\hline 13 & 7.88 & 23870 & 17167 & 9097 & 108 & 37.6 & 2.1 & 0.018 & $7 \times 10^{3}$ & $17 \times 10^{2}$ \\
\hline 14 & 7.63 & 343 & 190 & 12 & 152 & 6.4 & 3.15 & 0.23 & $160 \times 10^{3}$ & $160 \times 10^{3}$ \\
\hline 15 & 7.24 & 348 & 195 & 12 & 128 & 7.2 & 3.05 & 0.056 & $50 \times 10^{3}$ & $170 \times 10^{2}$ \\
\hline 16 & 7.9 & 338 & 190 & 10 & 140 & 5.2 & 3.25 & 0.052 & $26 \times 10^{3}$ & $170 \times 10^{2}$ \\
\hline
\end{tabular}

\section{Discussion}

The month of December in winter was chosen for the sampling as to have a clear idea of the diluting capacity of River Ganga. As monsoon was over so there were no dilution due to rain and also no excessive evaporation as observed in summer (when the pollutants may be very concentrated). The objective of choosing this sampling time was to get an idea of the correct pollution status of the river stretch in West Bengal, India. The time of sampling was low tide.

From the results of the present study it is found that all the study sites harbors both the TC and FC, in amounts in amounts that violate the drinking water standards set by the Bureau of Indian Standards (IS: 10500). It also violates the EPA standards as the EPA maximum contaminant level for coliform bacteria in drinking water is zero $\mathrm{TC} / 100 \mathrm{ml}$ of water [16].

The pattern of coliform distribution was irregular throughout the stretch as depicted in Figure 2, corroborated by the findings of Basu et al. [18] on River Hugli. There is also regular and rampant open defecation on the banks which contributes hugely to the coliform count. Thus, it can be said that the water of the study sites was much polluted in nature and the primary sources of these bacteria in water are the above mentioned. Huge drains carry the sewage mainly domestic and fall into the river further increasing the bacterial count [19]. Hence, this also indicates that there are sudden influxes of domestic sewage and industrial effluent into the river. Drains are also carriers of surface runoff, further increasing the coliform load [20]. The surface runoff carries soil particles which harbor and protect the bacteria invertebrate predators [21]. Research suggests that particles as small as $11 \mathrm{~mm}$ naturally occurring in surface water are able to harbor indigenous coliform bacteria and E. coli, subsequently offering protection from UV [22]. However, in the present study TSS did not have significant influence on coliform count. But its influence in other sites which were not under study cannot be ruled out. As observed, Garden Reach had the maximum coliform count because about fifteen drains discharge their effluents in the upstream of this station. The Garden Reach Sewage Treatment Plant was also monitored and was found to contribute about $94 \times 10^{7} \mathrm{MPN} / 100 \mathrm{ml}$ of TC, $17 \times 10^{7} \mathrm{MPN} / 100 \mathrm{ml}$ of FC, to Ganga. Some of the major drains are falling in to River Ganga clearly shows that there is high influx of TDS, BOD and COD acting as nutrients and source for coliforms. In drains the nitrogen is mostly in ammonia form as oxygen content is almost negligible. Hence the amount of nitrites and nitrate nitrogen is very low. Thus drains do not generally contribute towards nitrates and nitrite forms of nitrogen. The dilution factor nullifies the effects of these sudden influxes to some extent but their contribution as disturbances to this river is massive.

The minimum count was found at Ganga Sagar not because of purity but due to salinity which was measured in terms of chloride content (9097 $\mathrm{mg} / \mathrm{l})$ and salinity is 15.46 ppt. Salinity affects faecal bacterial viability by 
increasing the cell inactivation [23]. Moreover, sunlight inactivation of Escherichia coli is known to increase strongly with $\mathrm{pH}$ greater than 8.5 . In the entire stretch the $\mathrm{pH}$ did not exceed 8.15. Another source of pollution may be mass bathing into the holy river which continues throughout the year.

There is a huge rise in $\mathrm{Ca}^{2+}, \mathrm{Mg}^{2+}$, total hardness, TDS, chloride, alkalinity. Here the river water mixes with the Bay of Bengal. Thus this point also depicts the load of pollutants of river to the ocean. The conductivity does not fluctuate much along the river stretch. However, it increased abruptly in Ganga Sagar due to salinity of the ocean. Conductivity is not supposed to have any direct effect on coliform as conductivity is the measure of free ions. These ions may be nutrients for the coliform or may be harmful for them. Salinity increases conductivity but reduces coliform. Presence of nitrogen and phosphorus compounds increases the conductivity and also the coliform count. Our findings are further supported by Sayeda et al. [24] who diligently worked on river Nile.

\section{Conclusion}

The expected correlations between the physical and chemical parameters did not exist, indicating highly disturbed riverine ecosystem. Sudden and huge waste loading is not allowing the river to maintain its resilience. As a result, normally observed trends in correlations are missing. The holy river needs attention and waste should be discharged only after proper treatment in order to restore the holiness of Ganga. Regular water quality monitoring to establish baseline pollutant levels, identify pollution sources, and coordination of water cleanup activities among all basin stakeholders. Stream restoration activities to increase shading, improve microclimate conditions, reduce erosion, and provide buffers from pollution generating activities, and improvement of substandard and poorly functioning storm water detention facilities and increased maintenance of storm water detention facilities where necessary.

\section{Acknowledgments}

The authors acknowledge with gratitude and support from Central Pollution Control Board, Ministry of Environment and Forest, Government of India. Thanks are also due to National Ganga River Basin Authority, India for financial support and opportunity to conduct such a study.

\section{Reference}

[1] Afraz, A., 1994. The final report on the phenomenon of selfpurification of the Pirbazar River. Gilan Fisheries Research Institute, pp: 1-127.

[2] Afraz, A. and Gane, A., 1995. Biological and non-Biological Evaluation of the Hevigh River. Fisheries Research Centre of Gilan province, pp: 1-64.
[3] Emtiyazi, G., 2000. Microbiology and control of Climate, water and wastewater. Mony Publications, pp: 1-200.

[4] Malzad, F. and Fraz, A., 1995. Biological and non-biological evaluation of the Shafaroud River. Fisheries Research Centre of Gilan province, pp: 65.

[5] Khatib, S., 2005. Determining the extent of coliform pollution of the Hevigh River located in the West of Maragheh Province and its effects on aquatic life. National Conference on Fisheries and sustainable development. Ghaemshahr Islamic Azad University, pp: $1-80$.

[6] Central Pollution Control Board, 1984. Basin Sub-Basin Inventory of Water Pollution-The Ganga Basin. Part II. ADSORBS/7/198283.

[7] Mc Daniels, A.E., Bordner, R.H. Gartside, P.S. Haines, J.R. Conner, K.P. \& Rankin, C.C. 1985. Holding effects on coliform enumeration in drinking water samples. Applied and Environmental Microbiology, 50, pp: 755-762.

[8] Sood, A., Singh, K.D. Pandey, P. and Sharma, S., 2008. Assessment of bacterial indicators and physicochemical parameters to investigate pollution status of Gangetic river system of Uttarakhand (India). Ecological Indicators, 8 (5), pp: 709-717.

[9] EPA, 1997. Monitoring Guidance for Determining the Effectiveness of Nonpoint Source controls. EPOA 841-B-96-004. Washington, DC: U.S. Environmental Protection Agency.

[10] Young, K.D., and E.L. Thackston, 1999. Housing density and bacterial loading in urban streams. Biostatistical analysis (4th ed.), Singapore: Pearson Education.

[11] Frenzel, S.A. and Couvillion, E.S., 2002. Feca1 indicator Bacteria in streams along a gradient of residential development. Journal of the American Water Resources Association, 28 (1), pp: 265-273.

[12] Inamdar, S.P., Mostaghimi, S., Cook, M.N., Brannan, K.M., and McClellen, P.W., 2002. A Long-term, Watershed-scale, Evaluation of the Impacts of Animal Waste BMPs on Indicator Bacteria Concentrations. Journal of the American Water Resources Association, 38 (3), pp: 819-833.

[13] Steve H., Damon P., Michelle W., Gopal P., Rajesh K.M., Veer B.M., Catherine P. and Timothy E.F. 2013. Sewage pollution of the River Ganga: an ongoing case study in Varanasi, India, River Systems. 20/3-4, pp: 157-167.

[14] Basant R. 2013. Pollution and Conservation of Ganga Riverin Modern India International Journal of Scientific and Research Publications, 3, (4).

[15] Anjum P., Rajesh K., Pratima and Rajat K. 2013. Physio-Chemical Properties of the Water of River Ganga at Kanpur. International Journal of Computational Engineering Research, 3 (4), pp: 134-37.

[16] APHA, AWWA, WEF, 2005. Standard Methods for the Examination of Water and Wastewater $\left(21^{\text {th }} \mathrm{Ed}\right)$. Washington, DC: American Public Health Association.

[17] Central Pollution Control Board. 2008. Guidelines for Water Quality Management. Parivesh Bhawan, East Arjun Nagar, Delhi.

[18] Basu, S., Banerjee, T., Manna, P., Bhattacharyya, B. and Guha, B., 2012. Influence of Physicochemical Parameters on the Abundance of Coliform Bacteria in an Industrial Site of the Hooghly River, India. Proc. Zool Soc. DOI 10.1007/s 12595-012-0054-z.

[19] Lenihan, H.S., Oliver, J.S. Oakden, M.D. and Stephenson, M.D., 1990. Intense localized benthic pollution around McMurdo Station, Antarctica. Mar. Pollut. Bull., 21, pp: 422-430.

[20] Murdoch, T. and Cheo, M., 1996. Streamkeeper's Field Guide. Adopt-A-Stream Foundation.

[21] Marino, R.P. and Gannon, J.J., 1991. Survival of faecal coliform and faecal Streptococci in storm drains sediment. Wat. Res., 25 (9), pp: 1089-1098.

[22] Cantwell, R.E., Raymond, E. and Hofmann, R., 2008. Inactivation of indigenous coliform bacteria in unfiltered surface water by ultraviolet light.

[23] Anderson, I.C., Rodes, M.W. and Kator, H.I., 1979. Sublethal stress in Escherichia coli Escherichia coli: A function of salinity. Appl. Environ. Microbiol, 38, pp: 1147-1152.

[24] Sayeda, M.A., Z.S. Shawky, F. Mohammed, M. Mohammed and Nabil H.A., 2011. The influence of agro industrial effluents on River Nile pollution, Journal of Advanced Research, 2 (1): 85-95. 